\section{Determinants of purchase intention of traditional handloom apparels with geographical indication among Indian consumers}

Traditional handloom apparels

\author{
Sangeetha K. Prathap and Sreelaksmi C.C. \\ School of Management Studies, Cochin University of Science and Technology, \\ Kochi, Kerala, India
}

Received 17 April 2020 Revised 22 July 2020

29 September 2020

11 October 2020

Accepted 11 October 2020

\begin{abstract}
Purpose - Consumers often face a dilemma regarding the purchase decisions of traditional handloom apparel because of the non-availability of information cues that would enable them to assess the quality of the product. The spread of counterfeit products in the market adds to information asymmetry. The study aims to examine factors influencing purchase intention of traditional handloom apparel that have Geographical Indication (GI) certification, which follows the certification procedure specified by the World Intellectual Property Organisation (WIPO).

Design/methodology/approach - A survey was conducted among 202 traditional handloom apparel consumers in India and the data was analysed using structural equation modelling. The purchase intention of GI certified handloom apparels was examined as the dependent variable, whereas quality consciousness, product diagnosticity, perceived information asymmetry were placed as independent variables. The mediating role of perceived quality and product trust in the relation between perceived information asymmetry and purchase intention was also looked into.

Findings - Results reveal that quality consciousness positively influences product diagnosticity (facilitated by the GI label certification) which in turn reduces perceived information asymmetry. Further, a reduction in perceived information asymmetry was found to increase the purchase intention of traditional handloom apparel, fully mediated by the perceived quality and product trust.

Research limitations/implications - The customers who are facing a dearth of information while making purchase of traditional handlooms will be benefitted from the GI certification label which provides authenticity regarding product attributes confirming quality. Further, the study adds to the theory by establishing the relation between quality consciousness and perceived information asymmetry.

Practical implications - The findings imply that GI handloom apparel sellers should design marketing strategies that would project GI certification labels for traditional handloom apparel to effectively communicate product quality attributes, thus enhance product diagnosticity reducing information asymmetry. While organic certification for agricultural products is done at the individual producer's level, GI certification is done under the producer's collective label. Further, studies may be extended to agricultural products (Darjeeling tea, Alphonso mangoes, etc.), food items (rasgulla, Thirupathi laddoo, etc.) and handicrafts (Aranmula Mirror, Payyannur pavithra ring) that have acquired GI label in India. GI certification is adopted worldwide and studies may be extended to such products also [example Parma ham (Italy), Hessian wine (Germany)].
\end{abstract}

(C) Sangeetha K. Prathap and Sreelaksmi C.C. Published in Journal of Humanities and Applied Social Sciences. Published by Emerald Publishing Limited. This article is published under the Creative Commons Attribution (CC BY 4.0) licence. Anyone may reproduce, distribute, translate and create derivative works of this article (for both commercial and non-commercial purposes), subject to full attribution to the original publication and authors. The full terms of this licence maybe seen at http:// creativecommons.org/licences/by/4.0/legalcode

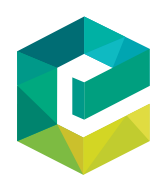

Journal of Humanities and Applied Social Sciences Vol. 4 No. 1, 2022 Emerald Publishing Limited 2632-279X DOI 10.1108/JHASS-04-2020-0055 
$\underset{4,1}{\text { JHASS }}$

22

Originality/value - Empirical research on determinants of consumer purchase intentions of GI certified traditional handloom apparel is a novel attempt done in the context of a developing country such as India. The study brings out the importance of the GI certification label envisaged by the WIPO, which can serve as a tool for reducing uncertainties faced by consumer in framing purchasing intentions. This can be extended to any product type such as agricultural, food products and handicrafts that has acquired GI certifications in different countries. The study revealed that product diagnosticity (through GI certification) could reduce perceived information asymmetry that leads the consumer to the perception of quality and product trust which results in the purchase intention of traditional handloom apparel. The outcomes of the study can be instrumental in designing marketing strategies for capturing market share.

Keywords Purchase intention, Quality consciousness, GI handloom apparels, Perceived information asymmetry, Product diagnosticity

Paper type Research paper

\section{Introduction}

Product quality concerns affect a consumer's decision to purchase traditional handloom apparel. The traditional handloom apparel consumers are largely affected by the issue of identifying the originality of products available in the market that face competition from near to similar products from power looms. The counterfeit products are similar in appearance but are inferior in quality when compared to handloom products. This often puts the consumer in a dilemma that they are often not able to identify the genuine product. The concept of reputation is a solution to the consumer's dilemma where decision-making is constrained by the asymmetry of information (Stiglitz, 1989; Maskin and Tirole, 1990). The effectiveness of such a solution may be ensured by institutionalizing reputation reducing information asymmetries.

The problem of asymmetric information exists between the traditional handloom apparel producers and consumers in India, where consumers are not able to identify the genuine handloom apparel in the market in the absence of a distinguishing label. Consumers always tend to maximise utility by making optimal choices; however, the choices could be exercised only on deriving sufficient information from the market place. The theory of information and reputation states that information asymmetry can give rise to distortions in the market when the attributes of a product are unrevealed (Rangnekar, 2004). Sellers of high-quality products are likely to face unfair competition from low-quality product sellers in terms of price competition. However, consumers are more likely to develop brand loyalty and willingness to pay a premium for reputation (Bramley et al., 2009). Geographical Indications (GIs), intellectual property in the era of TRIPS can serve as a legal instrument that institutionalises the connection of the product and geography in which they are produced, providing reputation thus benefitting the stakeholders (Bramley et al., 2009). This certification enables the protection of stakeholders; with the consumers being served with information of origin and quality and producer offered with product certification that connotes reputation (Aggarwal et al., 2014). Printed certification acts as a seal of approval from the certification body, which helps the consumer to be convinced about the authenticity of the product (Nazlida et al., 2017). A GI label or tag enables authenticity gained by the product through GI certification. This is similar to the concept of trademark in industrial parlance. Unlike organic certification, which comes at a direct cost to the producer (both for initial certification and maintenance), there is no cost attached to GI certification. Producer's collectives enroll for GI certifications and members in the collectives could produce the product following the standardised procedures, which bears an exclusive approved name. GI registration status conveys origin attributes, quality and authenticates the label. GI certification labels promise trustworthiness, thus reduces consumer's search costs along with curbing free-riding (Gangjee, 2017). 
Indigenous knowledge in rural communities can lead to the production of ethnic products. GI provides a guard of exclusivity to indigenous traditional methods of production confined to certain geographies, thus enabling the producer to take advantage of its exclusivity. GIs are attributed to leverages that help to project the uniqueness and originality of the product, thus enabling producers to charge a premium price and serve as an identification tool against counterfeit goods (Aggarwal et al., 2014). Examples of GI certified products are Parmesan Cheese and Parma Ham (produced in Parma region of Italy), Champagne (produced from grapes grown in Champagne region in France), Darjeeling tea (tea grown in Darjeeling region in India) and Swiss watches (high quality watches made in Switzerland).

Extensive research on traceability systems in similar lines in food quality contexts are found in the literature. Piemkhoontham and Ruenrom (2010) found that Thai consumers were willing to purchase meat with traceability labels at premium prices which ensured safe to eat quality. However, pre-purchase decision-making of a consumer and the factors that he might consider in identifying a quality product remains unclear and needs investigation. Many studies have focussed on demographic variables influencing the purchase intention of GI-labelled products. Very few studies have concentrated on developing causal models in consumer response to GI labels when it comes to the purchase of indigenous apparel. The present study attempts to fill this gap by exploring the influence of product diagnosticity provided by the GI label on perceived quality which leads to consumer trust and purchase intention. The study intends to contribute to the traditional handloom apparel marketing sector by conducting a study among domestic Indian handloom apparel consumers. The study probes the factors that consumer considers in formulating purchase intention of handlooms apparels having GI label. Consumers with strong quality consciousness are likely to explore product attribute related information and match them with their expectations before making a purchase. The effect of other factors comprising product diagnosticity, perceived information asymmetry, perceived quality and trust are verified. Structural equation modelling has been used to study and validate the causal model.

\section{Literature review}

\subsection{Geographical indication labels}

The indication of geographical origin is related to natural and human factors that are linked to geographic region. Such registry offers brand value and non-duplicability of the product, traceable to its geographic origin, where the customer derives the benefit of availing a "credence good", whereas the producer will be able to encash his produce at best available price with the genuine customer. GIs are defined by Article 22 of The Uruguay Round Agreement of TRIPS under World Trade Organization:

[...] as indications which identify a good as originating in the territory of a member, or a region or locality in that territory, where a given quality, reputation or other characteristics of the good is essentially attributable to its geographical origin.

GI provides legal protection to the public against the misrepresentation of product to be originated from particular geography (with peculiarity) other than its true place of origin. World Intellectual Property Organisation signifies that GI certification could be used on products that derive qualities and characteristics that are attached to the place of origin. It confers the rights to producers to prevent the use of the name by a third party whose product does not conform to predefined standards (Vinayan, 2012).

The Geographical Indication (GI) Act 1999, in India, provides legal backing by providing GI certification for quality/reputation/other characteristics of agricultural/natural/manufactured 
JHASS 4,1

products linked with geographic origin. The Act provides the right to use the tag (GI label) to a member of the community of producers or to any organisation which acts as the registering body. Though intellectual property falls under "private rights" under TRIPS, GIs are predominantly governed by the "public" or the state. The authorised registrant enjoys the right to use the GI label to further the cause of producers (Aggarwal et al., 2014). GIs and brands play similar roles in product differentiation (Deselnicu et al., 2013); thus GIs can be considered capable of providing successful branding of origin and quality which can create a brand pull enhancing the demand for the product (Fotopoulos and Krystallis, 2003; Gangjee, 2017; Verma and Mishra, 2018). Geographic associations of the product can act as quality cues linked to the quality characteristics of the product (Dimara and Skuras, 2003). Thus GI label acts as a tool to reduce information asymmetry between producers and consumers because of endorsement of features of geography, quality and reputation of the good by the label (Vinayan, 2017).

The study aims to understand consumers' perception of GI labels that act as a decision support mechanism in the traditional handloom apparel consumer context. This is relevant in a traditional handloom apparel market, where it is difficult to distinguish cloth manufactured by hand-operated loom from that of the mechanised loom. Chendamangalam Handlooms, Kuthampulli handlooms, Kasaragod Sarees and Balaramapuram handlooms in Kerala in India have been authenticated under the GI registry to bear GI label. GI has been introduced to support the authentication of products that tend to have a place of origin coupled with indigenous practices/traits. This also acts as legal protection, where the GI label pre supposes the existence of reputation (Bramley et al, 2009). Also, the GI label serves as an effective instrument to create differentiation among products (Deselnicu et al., 2013).

One of the peculiarities of GI is that, only designated manufacturers will be able to use the registered name, the violation of which attracts legal consequences. From the producer's perspective, promoting products through the GI label will provide assurances to customers about the authenticity of the products purchased by them. GI labels allow the consumers to identify the genuine product in terms of quality and gain trust in the product that meets the needs of a quality-conscious customer. In other words, the diagnosticity of the product is being ensured by the GI label which tends to annihilate the information asymmetry among the buyer and seller in terms of identifying the features of an authentic product. However, producers in the country are small and unorganised to encash the opportunity of branding in terms of the GI label and concentrate on market presence by differentiating from counterfeit products, reaching out to the quality conscious consumer who prefers a genuine product.

In the two-way process where sellers and consumers use the GI authentication label as a quality assurance mechanism that facilitates the reduction of information asymmetry between them. The sellers need to understand the factors that consumers consider while making decision to purchase traditional handloom apparel. There are similar studies in the context of food safety and quality systems which have looked into traceability systems. However, most of the studies in the traditional handloom context concentrate on the demographic variables that lead to consumer willingness to pay a premium price and purchase intention and studies related to legal issues and concerns regarding the protection of intellectual property (Rahmah, 2017; Vats, 2016). A study on branding and marketing of GI products in India explored the gaps in unlocking the commercial potential of GI products found that GI products marketing faced challenges in terms of limited consumer awareness and the absence of brand building and visibility (Sharma and Kulhari, 2015). This study looks into the factors including psychographic variables that can shape traditional handloom apparel consumer's behaviour purchasing decisions. The study intends to 
develop a conceptual model that would investigate the antecedents in making purchase decisions of traditional handloom apparels that have GI certification and labelling. The principal agent theory has been adopted as the framework of the study.

Traditional handloom apparels

\subsection{Principal-agent theory}

The phenomenon of information asymmetry that deters decision making may be examined with the principal-agent theory. The theory explains the relationship between the agent and the principal under the situation of information asymmetry. In the marketing context, the principal is the customer and the agent is the seller. The prospective buyers search for product-related information for making purchase decisions, whereas the sellers may hide information from the buyers. Asymmetrical information can give rise to the risk of adverse selection (agent's character of misleading/hiding information) and moral hazard (when the principal is not able to access information). This information gap can give rise to inefficiency and imperfect markets which can cause a disadvantage to the principal (Rangnekar, 2004). Thus a consumer in the market may arrive at an incorrect decision because of incorrect information supplied by the seller. A handloom consumer being the principal faces the adverse selection constraint which makes inhibition in making a decision to purchase genuine handloom apparel. This is because of the flooding of markets with similar products from mechanised looms. An ordinary consumer may fail to identify a genuine one (authentic traditional handloom apparel) from the counterfeit by mere physical examination. This may be mitigated by monitoring efforts by an authentic third party other than the seller, to reduce the information gap (Poth and Selck, 2009). GI certification and labelling reduce the information asymmetry between traditional handloom consumers (principal) and the sellers (agents). Unlike the search/experience goods, the reputation of the product influences consumer preference for "credence goods" (Vinayan, 2017). The study intends to examine the effect of product diagnosticity facilitated by GI labelling in reducing information asymmetry that could lead to traditional handloom apparel purchase decisions. Other variables that have a bearing on the purchase intention of traditional handloom apparels are quality consciousness, perceived quality and product trust.

\subsection{Quality consciousness}

Product quality can be viewed by consumers at different levels. Quality conscious customers look for attributes of quality when it comes to the purchase of products. A quality consciousness consumer can be observed as a utilitarian shopper who strives to find the best quality in products (Sprotles and Kendall, 1986). Quality consciousness consumers also tend to be brand conscious and place more trust in the performance of trusted and advertised brands (Rubio et al., 2014). In the context of traditional handloom apparel purchase, consumers can depend upon GI certification labels which could serve as cues for inferring quality specifications, which in turn can influence consumers' purchase intentions. Also, the quality of GI products invariably depends on the place of production (Rahmah, 2017).

Bernués et al. (2003) analysed the role of information cues in assessing meat quality and shaping the attitude of purchase. The study identified characteristics of quality-oriented consumers as one who sought more information on traceability. Quality conscious consumers search for information regarding product quality before making any purchase decision which could be served by such a label.

\subsection{Product diagnosticity}

Product diagnosticity signifies the degree to which consumer is able to estimate that the product fulfils required quality by using their beliefs, experience or knowledge. The 
JHASS 4,1

consumer will not be able to take a decision in the absence of information regarding product evaluation (Kempf and Smith, 1998; Buaprommee and Polyorat, 2016). In the context of GI labelling, product diagnosticity refers to the consumers' faith in the product carrying a label that it would be authentic and bear the quality by confirming the indigenous manufacturing process provided by registration in the GI registry. Thus, product diagnosticity ensured by the GI label would positively influence product evaluation by the consumer that would ensure purchase intention. It is not possible for the consumer to identify the genuine handloom products by examining the quality by themselves because of similar counterfeit products spread in the market. Thus, the GI label acts as an instrument that can provide product information. It can protect consumers by providing trustworthy product information cues in the market place (Menozzi, 2006). The credibility of the label is also important in the context of confirming the quality of the label by product diagnosticity. It should be granted by a third party, unrelated to the producer or reseller and should be unrelated to the sales of the concerned product (Tomáš, 2020). There is a significant role of reputation (provided by the GI label) in reducing problems associated with information asymmetry between a seller and buyer (Bramley et al., 2009).

The following hypothesis is proposed on this basis:

H1. Quality consciousness positively affects product diagnosticity.

\subsection{Perceived information asymmetry}

Information asymmetry refers to the discrepancy of information between buyers and sellers where the buyer perceives that the seller is in possession of product-specific information. The sellers may convey information about the true quality of the product attributes through cues that enable product evaluation by the customer (Pavlou et al., 2007). In an imperfect market, the seller may manipulate the product information that the buyer is in a disadvantaged position while taking a purchase decision. Sources of information can act as inputs to buyers in reducing perceived information asymmetry (Buaprommee and Polyorat, 2016). Other than the seller, third parties (online reviews, third-party certifications) also may provide information cues that will enable thorough evaluation product diagnosticity which may prove advantageous to the consumer in reducing information asymmetry aiding purchase intentions. Product diagnosticity helps to reduce perceptions of information asymmetry regarding the product quality, thus helps to guard against an adverse selection of inferior products (Buaprommee and Polyorat, 2016). GI labels can provide informational cues that certify attributes and guarantee authenticity, safety and expansion of quality perception (Bramley et al., 2013):

H2. Quality consciousness negatively affects perceived information asymmetry.

H3. Product diagnosticity (negatively) positively affects perceived information (a) symmetry.

$H 3 a$. Perceived diagnosticity mediates the relationship between quality consciousness and perceived information asymmetry.

\subsection{Perceived quality}

Perceived quality can be conceived as the subjective valuation of the product quality/ attributes (Yoo et al., 2000) which is different from the measurable objective quality (Zeithaml, 1988). Perceived quality can be also viewed as a mental assessment of 
consumers that emanate from individual attitudes (Elena et al., 2019). Information cues can provide as a guide to product quality that enables consumers to cross-check with their expectations. However, it was found that when consumers are not able to check the quality of the product looking upon intrinsic quality, they tend to use country of origin information as a surrogate quality indicator (Elliott and Cameron, 1994). Non-marketing cues such as certification can help to reduce uncertainty which guides consumers in making purchase decisions (Weisstein et al., 2016; Keh and Sun, 2018). A GI based product has to adhere to quality specifications fixed previously and are subject to the inspection of third party certifying agencies (Zhao et al., 2014). Traditional handloom apparel customers will be able to identify a quality product by information cue that is provided by a GI certification label that ensures a product that conforms to expectations. Alternatively, the lack of assurance of quality attributes by the GI label can lead to consumer inhibition of willingness to pay/purchase. (Zhao et al., 2014):

H4. Perceived Information (a) symmetry (negatively) positively affects the perceived quality.

\subsection{Product trust}

Trust in a product is a psychological state that reflects sellers' transparency and integrity that meets consumers' expectations (Pavlou and Gefen, 2004). Trust in turn can influence purchase intentions (Chong, 2003). Product diagnosticity can lead to higher perceived product quality by reducing the possibility of choosing an inferior quality product. Higher the level of diagnosticity, consumers tend to have reduced information asymmetry resulting in consumer trust. Studies on traceability in food quality context have proved that traceability could be an effective mechanism of ensuring food safety and quality that would ensure trust (Jiang and Benbasat, 2004; Kher et al., 2010). GI label corresponds to the traceability label which provides authenticity (product diagnosticity) to the product quality by a legalised certification. Choe et al. (2009) found that increased product diagnosticity, informativeness and trust resulted in reduced information asymmetry, which in turn reduced uncertainty that favours product purchase decision-making.

In this context, the following hypothesis is proposed:

H5. Perceived Information (a) symmetry (negatively) positively affects product trust.

H6. Perceived quality positively affects product trust.

\subsection{Purchase intention}

Consumers generally show less confidence in identifying the originality of a product. Credence attributes in products make it difficult for consumers to judge product quality (Buaprommee and Polyorat, 2016). GI labelling authenticates the product providing visual identification marks such as trademark facilitates recognition of an authenticated product. This can be regarded as an extrinsic cue that supports consumers in taking a purchase decision. GI label can thus be regarded as a cue that asserts consumers about product quality. This will enable reducing the risk of purchasing an inferior good which does not meet consumer expectations of quality, thus increasing trust in the product (Choe et al., 2009). Consumers who are likely to associate GI labelled products with higher quality are likely to develop trust that will lead to purchase intention (Menozzi et al., 2015; Buaprommee and Polyorat, 2016). The study probes the direct effect of
Traditional handloom apparels 
JHASS

4,1

28

quality consciousness, product diagnosticity and perceived information asymmetry on purchase intention:

H7. Quality consciousness positively affects purchase intention.

H8. Product diagnosticity positively affects purchase intention.

H9. Perceived information (a) symmetry (negatively) positively affects purchase intention.

H8. Perceived quality leads to purchase intention.

H9. Product trust leads to purchase intention.

H9a. Perceived quality and product trust in series mediate the relation between perceived information asymmetry and purchase intention.

The conceptual model for the study is given in Figure 1.

\section{Methodology}

\subsection{Data collection}

The study was done among traditional handloom apparel customers in the south western region in India. The respondents were selected by purposive sampling and data collection was done by administering a questionnaire. To ensure that respondents have interest and involvement in usage of traditional handloom apparel, two questions regarding traditional handloom apparel usage and purchase were asked as inclusion criteria. Accordingly, those who had purchase experience and were in the habit of using handloom apparels were selected as respondents of the study. The traditional handloom apparel that are used in the southern part of India includes sarees (Indian adult female wear) and dhotis (Indian adult male wear). The study interviewed customers using popular GI certified traditional handloom apparels of Chendamangalam sarees and dhotis, Kasaragod sarees, Kancheepuram sarees, Banaras sarees, Kuthampully sarees and dhotis, Balaramapuram sarees and dhotis and Mysore silk sarees. After a brief study description of GI labels, the eligible participants were asked to fill in the questionnaire. In addition to the variables, demographic information was sought during the survey. The questionnaire was distributed among 325 respondents for which 232 responses were received (response rate of $71 \%$ ).

Figure 1.

Research model

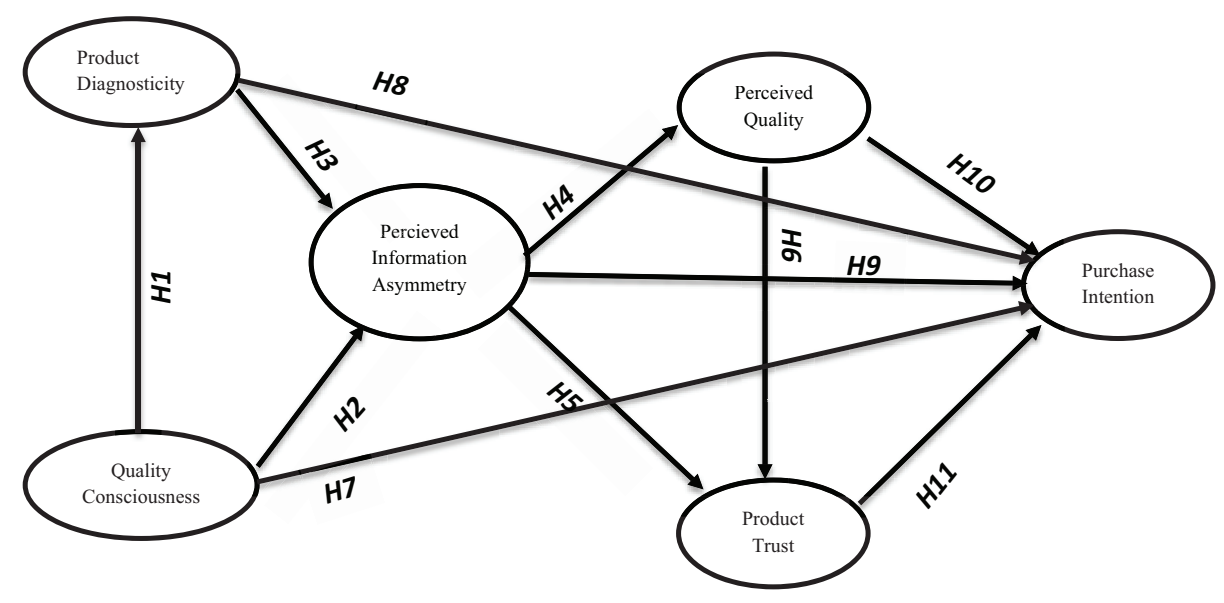


Incomplete questionnaires were abandoned; and the final sample consisted of 202 respondents. The profile of respondents included a majority of the female population $(62 \%$ female and $38 \%$ male) and age group of 46-55 years (75\%) and rest in (35-45 years) category.

\subsection{Measures}

The questionnaire contained statements of selected dimensions with a seven-point and fivepoint Likert scale with anchors ranging from strongly disagree (1) to strongly agree (7). The proposed conceptual model of the study comprises six constructs. All the constructs were measured using scales (containing multiple items) adapted from the previous literature and were modified to suit the context of the purchase of traditional handloom apparel. Quality consciousness was measured with three items (e.g. "it is important to me to buy high-quality products") adopted from Ailawadi et al. (2001). Product diagnosticity was measured with three items (e.g. "I expect the GI label to help me carefully evaluate traditional handloom products") adapted from Choe et al. (2009). Perceived information asymmetry was measured using two items (e.g. "GI label system reduces the degree of information gap on the "quality of traditional handloom products") between the producers and the consumers") adapted from Choe et al. (2009). Perceived quality was measured with three items (e.g. "The likely quality of traditional handlooms with GI label is high") adapted from Yoo et al. (2000). Product trust was measured with three items (e.g. "I trust traditional handlooms with GI label") adapted from Choe et al. (2009). Purchase intention was measured with three items (e.g. "I intend to increase the frequency of purchasing traditional handlooms with GI label") adapted from Choe et al. (2009).

\subsection{Data analysis}

The analysis used structural equation modelling because the conceptual model consists of more than one dependent variable which cannot be simultaneously tested with multiple regression analysis. After assessing the reliability and validity, confirmatory factor analysis (CFA) was carried out. Chronbach's alpha was calculated to establish construct reliability and convergent validity was established by average variance extracted (AVE), composite reliability $(\mathrm{CR})$ and standard loadings of each item to respective latent construct

\begin{tabular}{lccccc}
\hline Factor & Item & Standard loading & Cronbach's alpha & AVE & CR \\
\hline Product diagnosticity (PD) & PD1 & 0.800 & 0.892 & 0.740 & 0.895 \\
& PD2 & 0.864 & & & \\
Quality consciousness (QC) & PD3 & 0.851 & & & \\
& QC1 & 0.738 & 0.819 & 0.603 & 0.820 \\
Perceived information asymmetry (PIA) & QC2 & 0.788 & & & \\
PIA1 & 0.792 & 0.720 & 0.833 & 0.715 & 0.834 \\
Perceived quality (PQ) & PIA2 & 0.718 & & & \\
& PQ1 & 0.857 & 0.912 & 0.791 & 0.919 \\
Product trust (PT) & PQ2 & 0.881 & & & \\
& PQ3 & 0.841 & & & \\
Purchase intention (PI) & PT1 & 0.900 & 0.920 & 0.801 & 0.923 \\
& PT2 & 0.886 & & & \\
& PT3 & 0.875 & & & \\
& PI1 & 0.790 & 0.849 & 0.687 & 0.867 \\
& PI2 & 0.678 & & &
\end{tabular}

Traditional handloom apparels

$-$ 
$\underset{4,1}{\text { JHASS }}$

30

(Hair et al., 2010). By comparing the square root of AVE and the inter-construct correlation coefficient, discriminant validity was ensured (Fornell and Larcker, 1981).

Analysis proceeded down to establish the measurement model fit and further structural model fit was confirmed. Further path analysis was carried out to examine the causal relationships hypothesised in the study. The proposed hypothesis of mediation was analysed using Process Macro (Hayes, 2017).

\section{Analysis and results}

\subsection{Reliability and validity of the measurement model}

Descriptive statistics including means, standard deviations and correlations were examined. The measurement model was estimated using (CFA) using AMOS 23. Finally, the structural equation model was used to explore relationships between the six latent constructs including quality consciousness, product diagnosticity, perceived information asymmetry, perceived quality, product trust and purchase intention. Cronbach's alpha for the constructs of the study was found to be above 0.7, establishing construct reliability. Convergent validity of the constructs was measured using AVE and CR. AVE was greater than cut-off value of 0.50 ranging from 0.603 for quality consciousness to 0.801 for perceived quality; and CR values ranged between 0.820 and 0.919, greater than the cut-off value of 0.70 (Andersonand Gerbing, 1988; Hair et al., 2014).

Table 2 depicts the establishment of discriminant validity among the constructs, as the square root of AVE of all constructs (diagonally placed) is greater than their inter-construct correlation coefficients (Hu and Bentler, 1999; Hair et al., 2014).

Analysis of the measurement model yielded the following results. The ratio of chi-square to degrees of freedom $=1.206\left(\chi^{2}=125.422, \mathrm{df}=104\right)$; comparative fit index $(\mathrm{CFI})=0.991$; Tucker Lewis index $(\mathrm{TLI})=0.988$; IFI $=0.991$; normed fit index $(\mathrm{NFI})=0.950$; and root mean square error of approximation (RMSEA) $=0.032$. The measurement model depicts acceptable fit indices of CFI, NFI and TLI $>0.90$ and RMSEA $<0.08$ and $\chi^{2} / \mathrm{df}<5$.

\subsection{Structural model}

The study proceeded with estimating the structural model to test the proposed hypothesis. The fit indices obtained for the conceptual model are; chi-square to degrees of freedom $=1.203$ $\left(\chi^{2}=127.158, \mathrm{df}=108\right) ; \mathrm{CFI}=0.992 ; \mathrm{TLI}=0.990 ; \mathrm{IFI}=0.992 ; \mathrm{NFI}=0.947 ;$ and $\mathrm{RMSEA}=0.030$ indicating that the proposed conceptual model is acceptable (Hair et al., 2014).

\subsection{Path analysis}

The hypothesis formulated for the purpose of the study was tested using path analysis. Table 3 depicts the results of the path analysis. All hypotheses from $H 1$ to $H 6$ and $H 1 O$ and

\begin{tabular}{lrrrrrr}
\hline & PT & PD & QC & PIA & PQ & PI \\
\hline$P T$ & 0.895 & & & & & \\
$P D$ & 0.337 & 0.860 & & & & \\
$Q C$ & 0.363 & 0.649 & 0.776 & & & \\
$P I A$ & -0.400 & -0.827 & -0.760 & 0.846 & & \\
$P Q$ & 0.256 & 0.194 & 0.178 & -0.180 & 0.889 & \\
$P I$ & 0.411 & 0.080 & 0.139 & -0.090 & 0.696 & 0.829
\end{tabular}

Table 2.

Notes: Diagonal values in italic are square root of AVE; off-diagonal values are inter-construct correlation Discriminant validity coefficient 
$H 11$ were found to be significant with $p$-value $<0.05$. Figure 2 exhibits the unstandardized path coefficients and path significance. In all, $42.1 \%$ of the variance of the perceived diagnosticity was accounted for by quality consciousness $(\beta=0.832, p=0.000)$. Thus, hypothesis $H 1$ is supported. $77.8 \%$ of the variance in consumers' reduced information asymmetry was found to be influenced by perceived diagnosticity $(\beta=-0.496, p=0.000)$ and quality consciousness $(\beta=-0.435, p=0.000)$. Perceived information asymmetry was also found to influence perceived quality $(\beta=-0.252, p=0.010)$ with an $R^{2}$ of $3.9 \%$, and product trust $\left(\beta=-0.350, p=0.000\right.$ ) with an $R^{2}$ of $20 \%$. Thus, it could be inferred that reduced information asymmetry can lead to perceived quality and product trust. Further, the perceived quality was also found to influence product trust $(\beta=0.134, p=0.011)$. Finally, perceived quality $(\beta=0.335, p=0.000)$ and product trust $(\beta=0.214, p=0.000)$ were found to influence purchase intention with a variance of $56.5 \%$. The study could not find empirical evidence to support the hypotheses $H 7, H 8$ and $H 9$ which contain the direct influence of quality consciousness, perceived diagnosticity and perceived information asymmetry on the purchase intention.

\begin{tabular}{lrcccc}
\hline Hypothesis & $\beta$ & $\mathrm{CR}$ & $\mathrm{SE}$ & $p$-value & Decision \\
\hline H1: QC-PD & 0.832 & 0.107 & 7.799 & $* * *$ & Accepted \\
H2: QC-PIA & -0.435 & 0.093 & -4.685 & *** & Accepted \\
H3: PD-PIA & -0.496 & 0.070 & -7.037 & $* * *$ & Accepted \\
H: PIA-PQ & -0.252 & 0.098 & -2.569 & 0.010 & Accepted \\
H5: PIA-PT & -0.350 & 0.071 & 4.899 & $* * *$ & Accepted \\
H6: PQ-PT & 0.134 & 0.052 & 2.559 & 0.011 & Accepted \\
H7: QC-PI & 0.053 & 0.082 & 0.648 & 0.517 & Rejected \\
H8: PD-PI & -0.044 & 0.073 & -0.596 & 0.551 & Rejected \\
H9: PIA-PI & 0.093 & 0.116 & 0.803 & 0.422 & Rejected \\
H10: PQ-PI & 0.335 & 0.036 & 9.35 & $* * *$ & Accepted \\
H11: PT-PI & 0.214 & 0.047 & 4.576 & $* * *$ & Accepted
\end{tabular}

Traditional handloom apparels

Table 3. Results of path analysis



Figure 2. Validated research model 


\section{JHASS 4,1}

Table 4.

Results of simple mediation analysis

\subsection{Mediation analysis}

Often quality consciousness among the customers can lead to information seeking regarding the product which can result in information asymmetry. Simple mediation analysis was done to test the hypothesis that perceived diagnosticity mediates the relationship between quality consciousness and perceived information asymmetry. Mediation analysis was carried out by using the Process Macro recommended by Hayes (2017). The direct effect of quality consciousness on perceived information asymmetry was found to be significant. The indirect effect of quality consciousness on perceived information asymmetry through product diagnosticity also was found to be significant implying that there is a partial mediation (Table 4$)$. The indirect effect ( $\beta=$ Process 0.5632 ) was found to be higher than the direct effect $(\beta=0.3717)$. Thus, the hypothesis $H 3 a$ that product diagnosticity has a mediating effect on the relation between quality consciousness and perceived information asymmetry is accepted.

Serial mediation analysis has been used to analyse the hypothesis of mediation H9a that states the relation between perceived information asymmetry and perceived quality, product trust and purchase intention. The results of the analysis reveal the existence of full mediation between perceive information asymmetry and purchase intention by the construct's perceived quality and product trust. The result of serial mediation is presented in Figure 3 and Table 5 . The direct effect, indicating the relation between perceived information asymmetry and purchase intention was found to be insignificant (effect = $0.0047 ; \mathrm{CI}=-0.0334$ to 0.0429 ). The indirect effect (mediation) was found to be significant with two variables perceive quality and product trust that leads to purchase intention. The results indicate that a reduction in perceived information asymmetry among traditional handloom consumers can lead to an increase in perceived quality and product trust and thus enable the purchase intention of traditional handloom products. Simple mediations (PIA$\mathrm{PQ}-\mathrm{PI}$ ) (effect $=-0.1378$; $\mathrm{CI}=-0.2265$ to -0.0449 ) and (PIA-PT-PI) was also found significant (effect $=-0.0738 ; \mathrm{CI}=-0.1159$ to -0.0366 ).

\section{Discussion}

\subsection{Summary}

The study brings out the factors that influence a consumer's intention to purchase traditional handloom apparel. This has been investigated in the framework of the principalagent theory where information asymmetry forms the basis of consumers' decision-making of purchase of the product. The structural model reveals that various factors including quality consciousness, product diagnosticity, perceived information asymmetry, perceived quality and product trust have a significant influence on consumers' decision to purchase

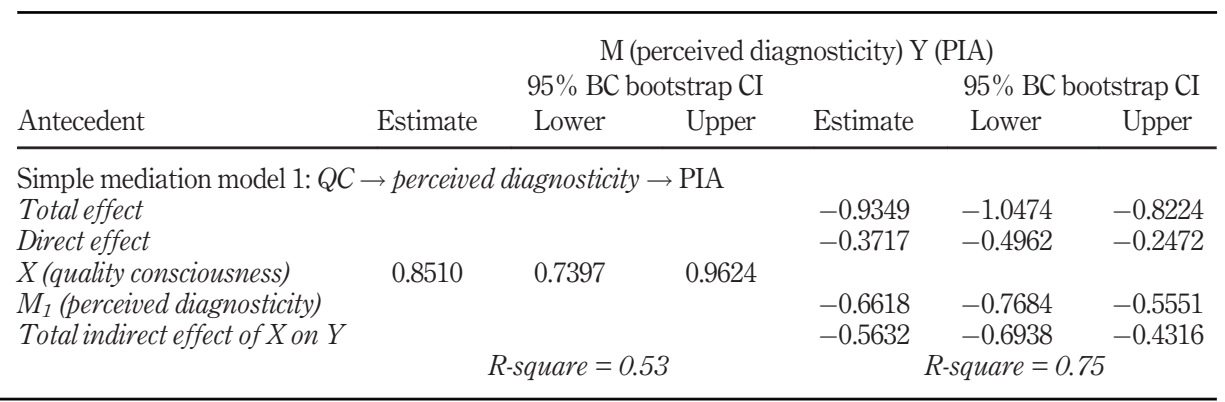




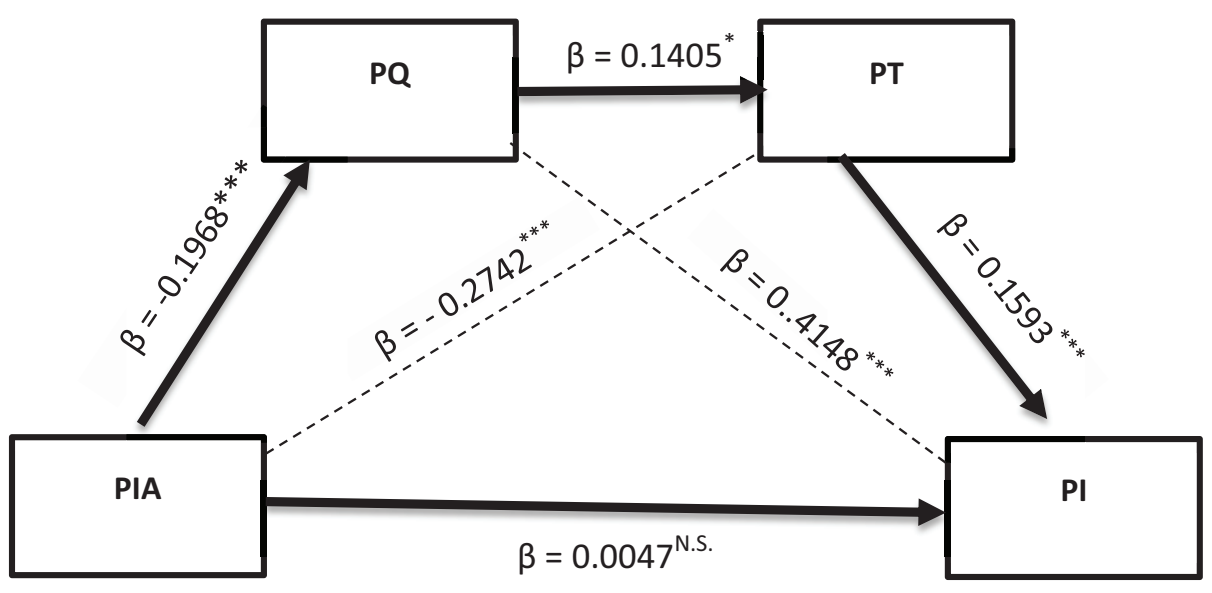

Traditional handloom apparels

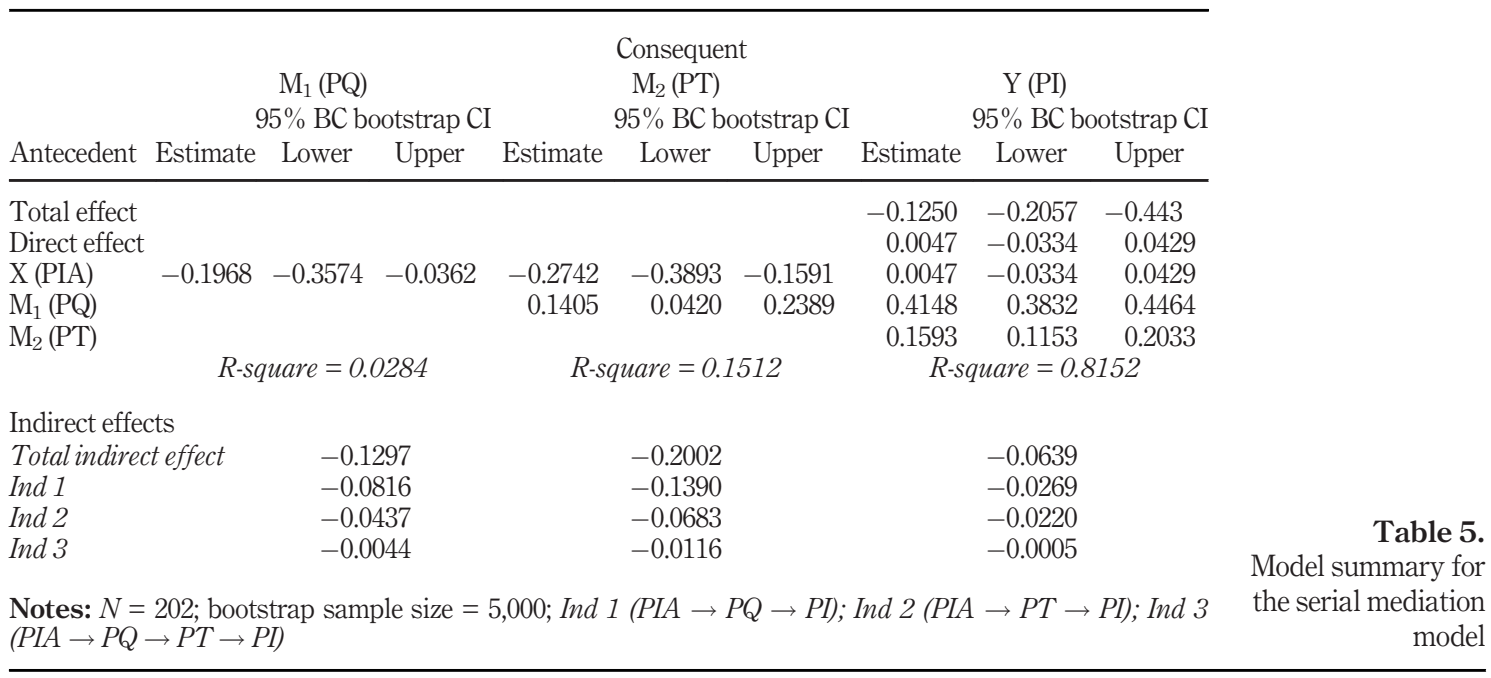

traditional handloom products. The authentication label that offers GI certification effectively works as a cue that reduces the information asymmetry of the buyer.

The study has validated the conceptual model based on principal-agent theory. It was found that GI certification labels can be effective in reducing information asymmetry in the marketplace which will assure the consumer about the expected quality of the product that will lead to purchase intention. Though such studies are available in food quality literature, this is the first study carried out in the context of GI certified handlooms. The model validates the significance of variables including quality consciousness, product diagnosticity, perceived information asymmetry, perceived quality and product trust in conformity with the results in food quality contexts.

The direct relationship between quality consciousness, perceived diagnosticity and perceived information asymmetry on the purchase intention was found to be insignificant. 
$\underset{4,1}{\text { JHASS }}$

These factors were found to influence product quality and trust and which in-turn affects purchase intention. Accordingly, the study validated the serial mediating effect of product quality and trust in the relation between perceived information asymmetry and purchase intention (full mediation).

\subsection{Theoretical implications}

The findings add to the literature in traditional product marketing with regard to the purchase intention of traditional handloom products with GI certification labels. The study validates factors including quality consciousness, product diagnosticity, perceived information asymmetry, perceived quality and product trust and therefore offers a comprehensive model of consumption of traditional handloom products. Furthermore, the research elucidates the method through which perceived information asymmetry shapes consumer purchase intention in this context. It was found that perceived quality and product trust mediates the relationship between perceived information asymmetry and purchase intention.

Relatively few studies have been carried out in developing economies that examine consumers' responses to GI certified traditional handloom apparel. The study fills this contextual gap by validating a model for purchasing intention of GI certified traditional handloom products in India.

Another implication of our model is the relevance of perceived information asymmetry being the decisive factor in inducing purchase intention. Perceived information asymmetry could be reduced by product diagnosticity where the GI label acts as the information cue that enforces quality attributes in a product. Quality consciousness was also found to have an influence on product diagnosticity implying that a consumer who is quality conscious will have a tendency to search for information cues that would reveal quality attributes in a product. Higher product diagnosticity implies a better evaluation of the product. In the study context, GI certified label awarded by the GI registry under government control guarantees authenticity as the label could be used only by designated producers. So it is likely that quality consciousness can inculcate information-seeking behaviour to ensure the quality of the product which can lead to better product diagnosticity, given that GI label is an information cue that could eventually mitigate adverse selection of inferior products. The findings are in line with the results of Buaprommee and Polyorat (2016) where they found a positive influence of quality consciousness on product diagnosticity. Also, the study reiterates the negative relation between product diagnosticity and perceived information asymmetry as found by Pavlou et al. (2007) and Choe et al. (2009). Further, the study contributes to the theory by establishing the relation between quality consciousness and perceived information asymmetry. Also, product diagnosticity was found to partially mediate the relationship between quality consciousness and perceived information asymmetry.

Another noteworthy result is the finding that perceived information asymmetry does not directly influence purchase intention. Our study finds an indirect impact of the perceived information asymmetry on purchase intentions via perceived quality and product trust which serially mediates between these relationships. Thus, it implies that a reduction in perceived information asymmetry can increase purchase intention by reinforcement of perceived quality of the product and trust created in the minds of the consumer. Also, a reduction in perceived information asymmetry was found to be partially mediated by product diagnosticity facilitated by the information cue (GI label). The findings are partially in line with the study of Buaprommee and Polyorat (2016) where they found that product trustfully mediated the relationship between perceived quality and purchase intention. The 
role of trust in reinforcing purchase intention was also reported by Van Rijswijk and Frewer (2008).

The constructs in the model were found to have a variability of $52 \%$, indicated by the $R^{2}$ for purchase intention of traditional handloom apparels. The predictive power of the model is high compared to similar studies in the food quality context $\left[\left(R^{2}=0.19\right)\right.$ for PI in Buaprommee and Polyorat, 2016].

\subsection{Managerial implications}

The study also offers several managerial implications. Traditional handloom apparel sellers in India can concentrate on the quality conscious consumers who would be concerned about purchasing quality products matching their expectations GI certification label could be upheld as a marketing tool which confirms the authenticity by institutional certification. Product diagnosticity enables evaluation of the product that possesses required quality specifications. Thus GI certification can provide confirmation of quality specifications and the certification offers a legalised compliance and is granted only to designated producers. It evolves from the study that, perceived information asymmetry could be reduced by dependence on the GI certification label. It reduces the information gap of a quality conscious consumer regarding quality attributes. Hence, the GI certification label can be sought upon by the consumer in his search for information cues to reduce information asymmetry. Further, the reduction of information asymmetry has been found to affect purchase intention as the consumers' perception of the quality will increase which leads to product trust. This is possible when the information asymmetry is reduced, facilitated by product diagnosticity offered by the GI label. The marketers should adopt effective communication strategies to educate consumers about the authenticity of the GI-labelled goods. Consumer confidence and trust in GI certified handlooms can be increased by this strategy. This gives implications for the policymakers. The government should come up with suitable promotional plans for popularising the authenticity of GI certifications as this would be supportive of the traditional handloom sector which is in a declining stage.

\subsection{Scope for further research}

Though many studies were carried out on GI products across countries, studies in the Indian context lacked momentum. The present study is confined to a single product, i.e. the impact of GI labelling on purchasing intention of Indian handloom apparels. It could be possible to extend the research across the globe by studying consumer intention to purchase Indian GI handlooms and other GI-labelled products such as agricultural products, handicrafts, etc. having its origin in designated geographies in the country. Further, one could explore hedonic value by studying the consumer willingness to pay a premium price for reputation, in lieu of information asymmetry that could open doors for future research. Consumer-level researches on how GI price premium are transmitted through the supply chains are scarce and need to be probed.

\section{Conclusion}

The study on purchase intention of traditional handloom products in India brings out the antecedents that affect consumer's purchase decisions. The principal-agent theory where the information asymmetry forms as a major deterrent in the consumer's product purchase decision were validated by the study. It was found that reduction in perceived information asymmetry could trigger the purchase intention of traditional handlooms. Such a reduction in perceived information asymmetry could be caused by the product diagnosticity offered by the GI certification label where the consumer will be well informed of the product. 


\section{JHASS 4,1}

Once the perceived information asymmetry is reduced, perceived quality and product trust is increased which helps the consumer to have a positive purchase intention of a highquality product. Future research may look into other factors such as pricing and promotion which does not come in the purview of this study. Considering the importance of GI certification label in reducing perceived information asymmetry that induces purchase intention of genuine traditional handloom apparel, more emphasis should be given by policymakers for popularising GI label products.

\section{References}

Aggarwal, R., Singh, H. and Prashar, S. (2014), "Branding of geographical indications in India: a paradigm to sustain its premium value", International Journal of Law and Management, Vol. 56 No. 6, pp. 431-442, doi: 10.1108/IJLMA-08-2012-0029.

Ailawadi, K.L., Neslin, S.A. and Gedenk, K. (2001), "Pursuing the value-conscious consumer: store brands versus national brand promotions", Journal of Marketing, Vol. 65 No. 1, pp. 71-89, doi: 10.1509/jmkg.65.1.71.18132.

Anderson, J.C. and Gerbing, D.W. (1988), "Structural equation modeling in practice: a review and recommended two-step approach", Psychological Bulletin, Vol. 103 No. 3, pp. 411.

Bernués, A., Olaizola, A. and Corcoran, K. (2003), "Labelling information demanded by European consumers and relationships with purchasing motives, quality and safety of meat", Meat Science, Vol. 65 No. 3, pp. 1095-1106, doi: 10.1016/S0309-1740(02)00327-3.

Bramley, C., Biénabe, E. and Kirsten, J. (2009), "The economics of geographical indications: towards a conceptual framework for geographical indication research in developing countries", The Economics of Intellectual Property, Vol. 109.

Bramley, C., Marie-Vivien, D. and Biénabe, E. (2013), Considerations in Designing an Appropriate Legal Framework for GIs in Southern Countries, Springer, Dordrecht, doi: 10.1007/978-94-007-6748-5.

Buaprommee, N. and Polyorat, K. (2016), "Intention to purchase traceable meat: the impacts of perceived information asymmetry, informativeness, usefulness, and norm”, Asia Pacific Management Review, Vol. 9 No. 1, pp. 141-168.

Choe, Y.C., Park, J., Chung, M. and Moon, J. (2009), "Effect of the food traceability system for building trust: price premium and buying behavior", Information Systems Frontiers, Vol. 11 No. 2, pp. 167-179, doi: 10.1007/s10796-008-9134-z.

Chong, B. (2003), "Why culture matters for the formation of consumer trust? A conceptual study of barriers for realizing real global exchange in Hong Kong”, Asia Paciifc Management Review, Vol. 8 No. 2, pp. 217-240.

Deselnicu, O.C., Costanigro, M., Souza-Monteiro, D.M. and Thilmany McFadden, D. (2013), "A meta-analysis of geographical indication food valuation studies: what drives the premium for origin-based labels? ", Journal of Agricultural and Resource Economics, Vol. 38 No. 2, pp. 204-219, doi: 10.22004/ag.econ.158285.

Dimara, E. and Skuras, D. (2003), "Consumer evaluations of product certification, geographic association and traceability in Greece", European Journal of Marketing, Vol. 37 Nos 5/6, pp. 690-705, doi: 10.1108/03090560310465099.

Elena, R.-D., Javier, B.-E.F. and Esmeralda, C.-A. (2019), "A cross-cultural analysis of perceived product quality, perceived risk and purchase intention in e-commerce platforms", Journal of Enterprise Information Management, Vol. 33 No. 1, pp. 139-160, doi: 10.1108/JEIM-06-2019-0150.

Elliott, G.R. and Cameron, R.C. (1994), "Consumer perception of product quality and the country-ofOrigin effect”, Journal of International Marketing, Vol. 2 No. 2, pp. 49-62, available at: www.jstor. org/stable/25048542.

Fornell, C. and Larcker, D.F. (1981), "Evaluating structural equation models with unobservable variables and measurement error", Journal of Marketing Research, Vol. 18 No. 1, pp. 39-50, doi: 10.2307/3151312. 
Fotopoulos, C. and Krystallis, A. (2003), "Quality labels as a marketing advantage”, European Journal of Marketing, Vol. 37 No. 10, pp. 1350-1374, doi: 10.1108/03090560310487149.

Gangjee, D.E.V.S. (2017), "Proving provenance? Geographical indications certification and its ambiguities", World Development, Vol. 98, pp. 12-24, doi: 10.1016/j.worlddev.2015.04.009.

Traditional handloom apparels

Hair, J.F., Black, W.C., Babin, B.J. and Anderson, R.E. (2010), Multivariate Data Analysis, Vol. 7, Prentice hall, Upper Saddle River, NJ.

Hair, J.F., Black, W.C., Babin, B.J. and Anderson, R.E. (2014), Multivariate Data Analysis, Prentice hall, Upper Saddle River, NJ.

Hayes, A.F. (2017), Introduction to Mediation, Moderation, and Conditional Process Analysis: A Regression-Based Approach, Guilford publications.

Hu, L. and Bentler, P.M. (1999), "Cutoff criteria for fit indexes in covariance structure analysis: conventional criteria versus new alternatives", Structural Equation Modeling: A Multidisciplinary Journal, Vol. 6 No. 1, pp. 1-55.

Jiang, Z. and Benbasat, I. (2004), "Virtual product experience: effects of visual and functional control of products on perceived diagnosticity and flow in electronic shopping", Journal of Management Information Systems, Vol. 21 No. 3, pp. 111-147, doi: 10.1080/07421222.2004.11045817.

Keh, H.T. and Sun, J. (2018), "The differential effects of online peer review and expert review on service evaluations: the roles of confidence and information convergence", Journal of Service Research, Vol. 21 No. 4, pp. 474-489.

Kempf, D.S. and Smith, R.E. (1998), "Consumer processing of product trial and the influence of prior advertising: a structural modeling approach", Journal of Marketing Research, Vol. 35 No. 3, pp. 325-338, doi: 10.2307/3152031.

Kher, S.V., Lynn, J.F., Janneke, D.J., Meike, W., Olivia, H.D., Niels, B.L.L. and Hilde, J.C. (2010), "Experts' perspectives on the implementation of traceability in Europe", British Food Journal, Vol. 112 No. 3, pp. 261-274, doi: 10.1108/00070701011029138.

Maskin, E. and Tirole, J. (1990), "The principal-agent relationship with an informed principal: the case of private values", Econometrica, Vol. 58 No. 2, pp. 379-409.

Menozzi, D. (2006), "Economic aspects of labelling regulations for consumer protection", Progress in Nutrition, Vol. 8, pp. 157-166.

Menozzi, D., Halawany-Darson, R., Mora, C. and Giraud, G. (2015), "Motives towards traceable food choice: a comparison between French and Italian consumers", Food Control, Vol. 49, pp. 40-48, doi: 10.1016/j.foodcont.2013.09.006.

Nazlida, M., Shiem, L.V. and Normalisa, M.I. (2017), "Does the country of origin of a halal logo matter? The case of packaged food purchases", Review of International Business and Strategy, Vol. 27 No. 4, pp. 484-500, doi: 10.1108/RIBS-06-2017-0049.

Pavlou, P.A. and Gefen, D. (2004), "Building effective online marketplaces with institution-based trust", Information Systems Research, Vol. 15 No. 1, pp. 37-59, doi: 10.1287/isre.1040.0015.

Pavlou, P.A., Liang, H. and Xue, Y. (2007), "Understanding and mitigating uncertainty in online exchange relationships: a principal-agent perspective”, Mis Q, Vol. 31 No. 1, pp. 105-136.

Piemkhoontham, T. and Ruenrom, G. (2010), "Perception and acceptance towards traceability system in selling meat products”, Chulalongkorn Business Review, Vol. 32 No. 123, pp. 73-107.

Poth, S. and Selck, T.J. (2009), "Principal agent theory and artificial information asymmetry: research and analysis", Politics, Vol. 29 No. 2, pp. 137-144, doi: 10.1111/j.1467-9256.2009.01349.x.

Rahmah, M. (2017), "The protection of agricultural products under geographical indication: an alternative tool for agricultural development in Indonesia", Journal of Intellectual Property Rights, Vol. 22 No. 2, pp. 90-103.

Rangnekar, D. (2004), Demanding Stronger Protection for Geographical Indications: The Relationship between Local Knowledge, Information and Reputation, INTECH. 
JHASS 4,1

Rangnekar, D. (2004), "Geographical indications UNCTAD-ICTSD project on IPRs and sustainable development intellectual property rights and sustainable development", Intellectual Property Rights and Sustainable Development, Vol. 4, pp. 1-53, available at: https:/iprsonline. org/resources/docs/Ragnekar-SocioEconomicsofGIs-Blue8.pdf\%0Ahttp://mamud.com/Docs/ originbasedproducts_full.pdf\#page $=84 \% 0 \mathrm{Ahttp} / / \mathrm{mamud} . \mathrm{com} /$ Docs/originbasedproducts_full. pdf\#page $=54 \% 0$ Awww.iprsonline.org/resources/docs/Rang

Rubio, N., Oubiña, J. and Villaseñor, N. (2014), "Brand awareness - brand quality inference and consumer's risk perception in store brands of food products", Food Quality and Preference, Vol. 32, pp. 289-298, doi: 10.1016/j.foodqual.2013.09.006.

Sharma, R. and Kulhari, H. (2015), Marketing of GI Products: Unlocking Their Commercial Potential, Center for WTOStudies.

Sprotles, G.B. and Kendall, E.L. (1986), "A methodology for profiling consumers' decision-making styles", Journal of Consumer Affairs, Vol. 20 No. 2, pp. 267-279, doi: 10.1111/j.1745-6606.1986.tb00382.x.

Stiglitz, J.E. (1989), "Principal and agent”, In Allocation, Information and Markets, pp. 241-253. Springer.

Tomáš, S. (2020), "Examining attitudes toward food quality labels: evidence from Czechia”, Journal of Food Products Marketing, Vol. 26 No. 3, pp. 197-211, doi: 10.1080/10454446.2020.1745347.

Van Rijswijk, W. and Frewer, L. (2008), "Consumer perceptions of food quality and safety and their relation to traceability", British Food Journal, Vol. 110 No. 10, pp. 1034-1046, doi: 10.1108/00070700810906642.

Vats, N.K. (2016), "Geographical indication-the factors of rural development and strengthening economy", Journal of Intellectual Property Rights, Vol. 21 Nos 5/6, pp. 347-354.

Verma, S. and Mishra, N. (2018), "Recognition and marketing opportunities of a "GI", Tag in Handloom Product: A Study of Banaras Brocades and Sarees, Vol. 23, pp. 101-110.

Vinayan, S. (2012), "Intellectual property rights and the handloom sector; challenges in the implementation of geographical indications act", Journal of Intellectual Property Rights, Vol. 17, pp. 55-63. Volpp .

Vinayan, S. (2017), “Geographical indications in India: issues and challenges-an overview”, The Journal of World Intellectual Property, Vol. 20 Nos 3/4, pp. 119-132, doi: 10.1111/jwip.12076.

Weisstein, F.L., Kukar-Kinney, M. and Monroe, K.B. (2016), "Determinants of consumers' response to pay-what-you-want pricing strategy on the internet", Journal of Business Research, Vol. 69 No. 10, pp. 4313-4320.

Yoo, B., Donthu, N. and Lee, S. (2000), "An examination of selected marketing mix elements and Brand equity", Journal of the Academy of Marketing Science, Vol. 28 No. 2, pp. 195, doi: 10.1177/0092070300282002.

Zeithaml, V.A. (1988), "Consumer perceptions of price, quality, and value: a means-end model and synthesis of evidence", Journal of Marketing, Vol. 52 No. 3, pp. 2-22, doi: 10.1177/ 002224298805200302.

Zhao, X., Finlay, D. and Kneafsey, M. (2014), "The effectiveness of contemporary geographical indications (GIs) schemes in enhancing the quality of Chinese agrifoods - experiences from the field”, Journal of Rural Studies, Vol. 36, pp. 77-86, doi: 10.1016/j.jrurstud.2014.06.012.

\section{Corresponding author}

Sangeetha K. Prathap can be contacted at: sangeethakprathap@gmail.com

For instructions on how to order reprints of this article, please visit our website:

www.emeraldgrouppublishing.com/licensing/reprints.htm

Or contact us for further details: permissions@emeraldinsight.com 